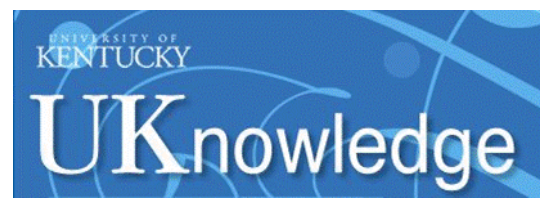

University of Kentucky

UKnowledge

Molecular and Cellular Biochemistry Faculty

Publications

Molecular and Cellular Biochemistry

11-16-2016

\title{
The Nuts and Bolts of the Platelet Release Reaction
}

Smita Joshi

University of Kentucky, smita.joshi@uky.edu

Sidney W. Whiteheart

University of Kentucky, whitehe@uky.edu

Follow this and additional works at: https://uknowledge.uky.edu/biochem_facpub

Part of the Biochemistry, Biophysics, and Structural Biology Commons

Right click to open a feedback form in a new tab to let us know how this document benefits you.

\section{Repository Citation}

Joshi, Smita and Whiteheart, Sidney W., "The Nuts and Bolts of the Platelet Release Reaction" (2016).

Molecular and Cellular Biochemistry Faculty Publications. 162.

https://uknowledge.uky.edu/biochem_facpub/162

This Review is brought to you for free and open access by the Molecular and Cellular Biochemistry at UKnowledge. It has been accepted for inclusion in Molecular and Cellular Biochemistry Faculty Publications by an authorized administrator of UKnowledge. For more information, please contact UKnowledge@lsv.uky.edu. 


\section{The Nuts and Bolts of the Platelet Release Reaction}

Digital Object Identifier (DOI)

https://doi.org/10.1080/09537104.2016.1240768

\section{Notes/Citation Information}

Published in Platelets, v. 28, issue 2, p. 129-137.

(๑) 2016 Taylor \& Francis

The copyright holder has granted the permission for posting the article here.

This is an Accepted Manuscript of an article published by Taylor \& Francis in Platelets on 16 Nov 2016, available online: http://www.tandfonline.com/10.1080/09537104.2016.1240768. 
Published in final edited form as:

Platelets. 2017 March ; 28(2): 129-137. doi:10.1080/09537104.2016.1240768.

\title{
The Nuts and Bolts of the Platelet Release Reaction
}

\author{
Smita Joshi and Sidney W. Whiteheart ${ }^{1}$ \\ Department of Molecular and Cellular Biochemistry University of Kentucky, USA
}

\begin{abstract}
Secretion is essential to many of the roles that platelets play in the vasculature, e.g., thrombosis, angiogenesis, and inflammation, enabling platelets to modulate the microenvironment at sites of vascular lesions with a myriad of bioactive molecules stored in their granules. Past studies demonstrate that granule cargo release is mediated by $\underline{\text { Soluble }} \underline{\mathrm{NSF}} \underline{\mathrm{A}}$ ttachment Protein $\underline{\text { Receptor }}$ (SNARE) proteins, which are required for granule-plasma membrane fusion. Several SNARE regulators, which control when, where, and how the SNAREs interact, have been identified in platelets. Additionally, platelet SNAREs are controlled by post-translational modifications, e.g., phosphorylation and acylation. Although there have been many recent insights into the mechanisms of platelet secretion, much still remains undefined. In this review, we focus on the mechanics of platelet secretion and discuss how the secretory machinery functions in the pathway leading to membrane fusion and cargo release.
\end{abstract}

\section{Keywords}

SNAREs; Munc18; Exocytosis; STXBP5; Munc13; Rab

\section{Introduction}

Platelets are discoid, anucleate cell fragments that contribute to normal hemostasis and, increasingly, their additional roles in inflammation, infection, wound healing, angiogenesis, and metastasis are receiving attention [1,2]. Release of granule content is central to most platelet functions because it allows platelets to modulate the microenvironment at sites where they are activated. Platelets contain three main types of granules- dense (also known as $\delta$-granules), $a$, and lysosomes-each with distinct contents and properties. Dense granules contain small molecules, e.g., ADP, ATP, serotonin, polyphosphate, and calcium, which have a role in amplifying hemostasis. Defects in dense granule biogenesis significantly increase bleeding. a-Granules contain a plethora of proteins with diverse function, e.g., mitogens, cytokines, and adhesive proteins. Defective a-granule biogenesis causes a more varied bleeding diathesis [3]. Lysosomes contain acid hydrolyses and proteases, which may contribute to clot remodeling. In this review, we discuss the mechanics of platelet granule release, with specific focus on the proteins required and how they function. For additional

\footnotetext{
${ }^{1}$ Corresponding Author Contact Information: Sidney W. Whiteheart, Ph.D., Department of Molecular and Cellular Biochemistry, University of Kentucky, 741 South Limestone Street, BBSRB B271, Lexington, KY 40536 USA, Phone: 859-257-4882, Fax: 859-257-2283, whitehe@uky.edu.

Declaration of Interests: The authors declare no competing financial interests.
} 
information, we recommend several excellent reviews that cover platelet granule biogenesis and secretion [4-7].

\section{Exocytosis by Platelets}

Platelet secretion is a textbook example of regulated secretion: there are stores of cargo in granules that are released upon stimulation with an agonist (often called a secretagogue). Platelets respond to many agonists; some, e.g., thrombin and convulxin, are considered strong and cause robust release while others, e.g., ADP and epinephrine are weak secretagogues. Secretion of dense granules is generally monitored by measuring ATP or serotonin release. $a$-Granule exocytosis is monitored by measuring the release of soluble cargo proteins e.g., Platelet Factor 4, thromboglobulin, von Wlillebrand Factor (vWF), or the surface exposure of P-selectin, an abundant a-granule membrane protein. Hydrolytic enzymes, such as $\beta$-hexosaminidase, are used as metrics of lysosome release. In many studies, single time points or agonist doses are used; however, this hides the complexity of the platelet exocytosis process. More detailed studies demonstrate that the rates and extents of platelet exocytosis are directly related to stimulation strength [8]. Dense granule release is the fastest, most sensitive process; lysosome release is the slowest and requires greater stimulation. a-Granule release is kinetically the most diverse. Together, these three exocytic processes form the platelet releasate, which has been shown to contain hundreds of bioactive components [9-12]. It is this releasate that affects the microenvironment around activated platelets and contributes to platelet function.

The content of the platelet releasate and how its composition is controlled have been the subject of great interest. Are platelets able to release only subsets of their cargo or is the process stochastic? Both unbiased proteomics and directed antibody array systems have been used to monitor the release of multiple cargos simultaneously. Several groups suggest that specific classes of cargo (e.g., pro-angiogenic and anti-angiogenic factors) can be released in response to specific agonists [13-15]. However, other studies detected no thematic patterns in cargo release. Jonnalagadda et al., using a custom microELISA array and four agonists (thrombin, convulxin, PAR1 and PAR4), showed that agonist potency influences the kinetics and extent of secretion, but there were no "functionally thematic" patterns in the release process [8]. Broader proteomic studies confirmed the lack of thematic patterns in the release of granule cargo [11,12]; however, there are distinct kinetic patterns with cargo release occurring in waves. These findings suggest that platelets can use distinct release rates to temporally affect their microenvironment. The kinetics of release may be governed by the degree of stimulation, the chemical properties of the cargo, the locale where the cargo is packaged in a granule and/or the machinery used $[8,16,17]$. Since most of these past studies were done in suspension, it is unclear if there are also spatial constraints on platelet secretion. Early electron microscopy studies suggest that the ventral platelet surface is different from the distal surface, consistent with some degree of polarity [18].

\section{Granule-Plasma Membrane Fusion}

The penultimate step of exocytosis is the fusion of cargo-containing granules with plasma membranes (PM). Platelet granules also fuse with one another, in a process called compound 
fusion, which may or may not precede fusion with the PM [19]. Membrane fusion is

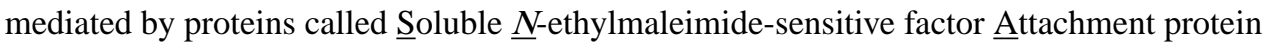
Receptor (SNARE) proteins (Figure 1). This process is highly conserved in all eukaryotes and the family of SNARE proteins is quite large [20]. SNAREs are classified into two groups based on their relative locations: $\mathrm{v}$ - for vesicle/granule-localized and $\mathrm{t}$ - for target membrane-localized. SNAREs are also classified based on the amino acid at the center of their SNARE domains, either R (Arg) or Q (Glu). Vesicle Asssociated Membrane Proteins (VAMPs) constitute a large group of the known v-SNAREs (R-SNAREs). t- SNAREs (QSNAREs) consist of two classes of proteins - Syntaxins and Synaptosome $\underline{\text { Associated }}$ Proteins/SNAP-23/25 proteins [21]. All SNAREs contain one or two amphipathic, heptadrepeat-containing, SNARE domains of $\sim 60$ amino acids; cognate $v$ - and t- SNAREs interact, through these domains, to form a transmembrane complex that promotes membrane fusion [22]. Four SNARE domains, one each from v- SNARE (R-SNARE) and Syntaxin $\left(\mathrm{Q}_{\mathrm{a}}\right.$ SNARE) and two from SNAP-23/25 ( $\mathrm{Q}_{\mathrm{bc}}$ SNARE), form a coiled-coil structure that buries the hydrophobic residues and draws the two membranes together for fusion.

\section{v-SNARE in Platelets}

Quantitative western blotting and proteomic analysis $[23,24]$ have shown that platelets contain multiple v-SNARE isoforms (e.g., VAMP-2,-3,-4,-5,-7,-8; Table 1). VAMP-8 and -7 are most abundant in human platelets while VAMP-8, -2 , and -7 are most abundant in mouse platelets. Although previous studies, using permeabilized platelets, showed a role for VAMPs, the assignment of specific isoforms was equivocal [25-28]. More definitive studies of platelets from knockout (KO) mice demonstrated roles for VAMP-8 and VAMP-7; however, in neither case does a single VAMP account for all of the release [29, 30]. Deletion of VAMP-3 or reduction of VAMP-2 had no effect when VAMP-8 and -7 were present [30]. Interestingly, permeabilized VAMP-8 KO mouse platelets did show diminished secretion upon treatment with tetanus toxin light chain fragment, which specifically cleaves VAMP-2 and -3 [31]. VAMP-7 is resistant to the toxin peptidase [32]. Taken as a whole, these data imply unique and dominant roles for VAMP-7 and -8 in platelet secretion, and also suggest that, at least in mice, VAMP-2 and -3 contribute to the process. This type of compensation or "ranked redundancy" in isoform usage has been reported in chromaffin cells [33] and in mast cells $[34,35]$. It may be related to some intrinsic property of each VAMP or to the amounts of each isoform. This distinction is not clear at present.

Phenotypically, the loss of VAMP-8 causes defective thrombosis. Global deletion of VAMP-8 resulted in delayed and diminished thrombus formation [24]. However, VAMP-8 KO mice failed to show any bleeding diathesis. Interestingly, loss of VAMP-7 caused no defect in platelet accumulation at the site of laser injury nor in the tail-bleeding assay, though a-granule release is affected in the growing thrombus [29]. These data support the primacy of VAMP-8-mediated secretion in hemostasis and suggest that VAMP-7 and VAMP-8 contribute distinctly to platelet function.

Consistent with the primacy of its usage, the gene encoding VAMP-8 has been linked, by Genome Wide Association Studies (GWAS), to early-onset myocardial infarction, which is indicative of hyper-reactive or perhaps "hyper-secretory" platelets [36, 37]. Additional 
genetic studies identified a microRNA that controls VAMP-8 expression and correlates with increased platelet response to epinephrine [38]. This microRNA affected VAMP-8 levels in a tissue culture system, but the effects on secretion were not tested. From the mouse models and the implications of the human genetic data, it seems possible that VAMP-8 levels directly affect platelet secretion efficacy.

VAMP-7 is structurally distinct from other, shorter VAMP isoforms (VAMP-2,-3, and -8). It contains a characteristic domain at its $\mathrm{N}$ terminus, called a Longin domain, which interacts

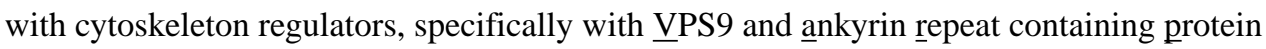
(VARP) [29, 39]. VAMP-7 positive structures localize to the periphery of spreading platelets, while VAMP-8 and VAMP-3 positive granules concentrate in the central granulomere [40]. These data imply that VAMP-7 mediates secretion at the periphery where it is needed for platelet spreading. VAMP-8 (and perhaps VAMP-2 or - 3) mediates fusion in the centralized granulomere, which is needed for thrombus growth. VAMP-8's role in platelet spreading has not been directly tested. Similar studies in neutrophils [41] and mast cells [42] also show a polarization of VAMP isoform-positive structures during the exocytosis process.

The spatial differences between VAMP-7 and VAMP-8 positive granules suggest the potential for differential cargo release mediated by the two isoforms. At present, it is unclear if the two VAMPs associate specifically with distinct cargo or mediate differential release in response to different secretagogues. However, the existing data offer intriguing hints about the spatial nature of platelet exocytosis. Future experiments using microfluidics and/or enhanced-resolution imaging, in vivo, will be needed to resolve these questions.

\section{t-SNAREs in Platelets}

Platelets contain Syntaxin 2, 4, 6, 7, 8, 11 12, 16, 17, and 18 and SNAP-23, 25 and 29 (Table 1) $[23,43]$. SNAP-23 is thought to be the functionally relevant $\mathrm{Q}_{\mathrm{bc}} \mathrm{t}$-SNARE, based on studies using permeabilized platelets with inhibitory antibodies and peptides [26, 44-46]. SNAP-25 is much less abundant and platelets from SNAP-29 KO mice show no significant secretion defect [47]. The $\mathrm{Q}_{\mathrm{a}} \mathrm{t}$-SNAREs, Syntaxin 2 and 4, were previously reported to be important [26, 44-46]. However, these findings were not consistent with data from KO mice [48]. Secretion from Syntaxin 2/4 double KO platelets is unaffected (though endocytosis is defective, Ye and Whiteheart unpublished). Analysis of platelets from a Familial Hemophagocytic Lymphohistiocytosis type 4 (FHL-4) patient, lacking Syntaxin 11, indicate its role in secretion from all three granules. Consistently, Syntaxin 11 forms complexes with SNAP-23 and VAMP-8. To explain previous data, Ye et al., showed that the original antiSyntaxin 2 antibodies, which inhibited release from permeabilized platelets, cross-reacted with Syntaxin 11. Recently, another report demonstrated that Syntaxin 8 influences dense granule but not a-granule or lysosome release [49]. The authors showed that Syntaxin 8 interacts with Syntaxin 11 but not with SNAP-23. This shows that Syntaxin 8's Qb SNARE motif forms different complexes with the $\mathrm{Q}_{\mathrm{a}}$ motif of Syntaxin 11 than the complexes formed with SNAP-23's $\mathrm{Q}_{\mathrm{bc}}$ motifs. 


\section{SNARE Regulatory Proteins}

SNAREs are essential for membrane fusion, but their associations to form membrane-fusing complexes are controlled temporally and spatially by several types of regulatory proteins and also by post-translational modifications of the SNAREs themselves (Figure 1 and Table 1). Some SNARE regulators are chaperones (e.g., the Sec/Munc proteins), while others promote the apposition of fusing membranes, indirectly (or directly) affecting SNARE association (e.g., Munc13, Rabs, STXBP5/Tomosyn 1, SLP4/granuphilin, etc.). These so-called docking factors also affect where fusion occurs.

\section{Munc18b}

The Sec1/Munc18 (SM) family of cytosolic proteins is crucial for membrane trafficking and exocytosis. In mammals, the seven SM proteins act as syntaxin chaperones, targeting and directing the t-SNARES to form specific SNARE complexes [50, 51]. Platelets contain VPS33a and 33b, which are involved in dense and a-granule biogenesis, respectively [52, 53]. Platelets also contain Munc18a, Munc18b and Munc18c (STXBP1, 2, 3); however, Munc18b is significantly more abundant [54]. Previous studies suggested that Munc18c contributes to platelet secretion by interacting with Syntaxin 4 [55]; however, platelets from Munc $18 \mathrm{c}^{+/-}$mice have normal secretion indicating that partial loss $(\sim 30 \%)$ of this isoform is insufficient to depress secretion [56]. Recent studies of FHL type 5 patients, which have defects in the gene encoding Munc18b, show that Munc18b is critical for platelet secretion from all three granule types [54]. Consistent with Munc18b's role as a chaperone, deficient platelets showed a decrease in Syntaxin 11; no other syntaxins were affected. Platelets from biallelic patients have robust secretion defects and heterozygous patients have intermediate deficits. Such haploinsufficiency suggests that Munc18b is limiting for the secretion process in platelets. Consistently, semi-quantitative western blotting data suggest that Syntaxin 11 and SNAP-23 are in molar excess over Munc18b in human platelets [48, 54]. Several reports suggest that the Munc18s are phosphorylated in platelets and that phosphorylation affects Munc18/Syntaxin interactions [55, 57, 58]. However, many of the studies focused on Munc18c, whose role in secretion is uncertain. Detailed studies of Munc18b phosphorylation in platelets have not been done.

\section{STXBP5/Tomosyn 1}

Another t-SNARE regulator is Syntaxin Binding Protein 5 (STXBP5), also known as Tomosyn 1, meaning friend (tomo) of syntaxin [59]. In neurons, STXBP5 is a negative regulator of exocytosis. STXBP5 contains WD-40 repeats, which are thought to interact with the cytoskeleton [60]. C-terminal of these repeats is a variable linker region with multiple predicted phosphorylation sites. Adjacent to the linker, is a v-SNARE-like domain that interacts with t-SNARE heterodimers (e.g., Syntaxin 11/SNAP-23) and is thought be a regulatory "place-holder". Consistently in platelets, STXBP5 antibody only precipitated tSNAREs but no VAMPs [61]. Surprisingly, platelet secretion is significantly diminished in platelets lacking STXBP5. Mice lacking STXBP5 showed a robust bleeding diathesis that exceeded expectations based on their secretion defect. The bleeding was due to defective platelet secretion based on bone marrow transplantation studies. 
A recent GWAS linked polymorphisms in the STXBP5 gene to increased plasma vWF and thus to increased risk of cardiovascular diseases [62, 63], which conflicts with the phenotype of the KO mice. Lowenstein and colleagues resolved this inconsistency by showing that STXBP5 negatively regulates Weibel Palade Body release from endothelial cells. Consistently, the KO mice had increased plasma vWF [64]. Interestingly, rs1039084, a nonsynonymous single nucleotide polymorphism (SNP) in the STXBP5 gene, correlated with increased bleeding [65]. Taken together, these data suggest that STXBP5 is a critical regulator of vascular health and plays distinct roles in both endothelial cells and platelets.

\section{Tethering and Docking Factors}

The factors discussed above directly control SNAREs; however, there are other factors that control secretion by affecting docking/tethering of granules to exocytosis sites. Many of these regulators are recruited from the cytosol through interactions with lipids and/or membrane proteins and once positioned, they promote SNARE engagement and enhance membrane fusion.

\section{Rab27}

Rab27a/b are small GTPases that direct granule docking and tethering in a number of secretory systems [66]. In a seminal study using Rab $27 \mathrm{a}^{-/-}$(ashen), Rab27b $\mathrm{b}^{-/-}$and Rab $27 \mathrm{a} / \mathrm{b}^{-/-}$mice, Seabra and colleagues [67] showed that only mice, homozygous for Rab $27 \mathrm{~b}$ loss, had a significant bleeding diathesis. Loss of Rab27a, alone, affected pigmentation but not bleeding. Detailed studies showed that Rab27b was important for dense granule release, but its loss had no effect on P-selectin exposure (a-granule release). Rab27b did appear to contribute to dense granule biogenesis since endogenous serotonin levels were lower in Rab27b ${ }^{-/}$platelets, irrespective of Rab27a's presence. Given the interactions between Rab27 and other elements discussed below (i.e. SLPs and Munc13-4), this small GTPase is a key to dense granule release in platelets.

\section{Munc13-4}

Munc13 proteins are a family of multi-domain proteins, which contain a characteristic Munc Homology Domain (MUN) domain and, at least, two calcium/lipid-binding C2 domains. Some also contain calmodulin and diacylglcerol (DAG) binding sites [68]. Munc13-4 is a known Rab27 effector [69]. In vitro studies with liposomes show that Munc13-4 bridges, but does not fuse, membranes in a calcium-dependent manner [70]. This clustering requires both C2 domains. Secretion is dramatically abolished in Munc $13-4^{-/-}$platelets. Consistently, Munc13-4 $4^{-/}$mice have a significant bleeding diathesis [71]. Quantitative analysis suggests that Munc13-4 may be limiting, which was confirmed by titration experiments using permeabilized Munc13-4 ${ }^{-/-}$platelets and in Munc13-4 $4^{+/-}$mice which had an intermediate phenotype. Loss of Munc13-4 also increased the in situ mobility of dense granules, which is consistent with its role as a docking/tethering factor [70]. Parenthetically, these results imply that dense granules are pre-docked in resting platelets, perhaps accounting for their rapid release rates.

Although Munc13-4 clearly plays a role in dense granule release, its role in a-granule and lysosome release is less certain. Ren et al. [71] showed that the a-granule and lysosome 
release defects in Munc13-4 $4^{-/}$platelets are less apparent at higher secretagogue concentrations. Poole and colleagues showed that ADP addition overrides much of the agranule secretion defect [72]. These data underline the fact that dense granule secretion deficiency precipitates defects in a-granule and lysosome release; a point that has been noted by others $[73,74]$. Thus, the autocrine signaling from released ADP plays a critical role in modulating a-granule and lysosome release.

\section{Synaptotagmin-Like Proteins}

Rab effectors such as synaptotagmin-like-proteins (SLPs) are present in platelets and appear to have both stimulatory and inhibitory roles [66]. Using a yeast two-hybrid assay, Smolenski and colleagues showed that SLP1 forms a trimeric complex with Rap1, a ras-like GTPase, and the Rap nucleotide exchange factor RAP1GEF2. SLP1 had a negative effect on dense granule release from permeabilized platelets while RAP1GEF2 addition increased release [75]. The same group showed that SLP4/granuphilin interacts with Rab8 in human platelets and its addition to permeabilized platelets enhanced dense granule release [76]. This enhancement required SLP4 binding to Rab8. SLP4 is also a Rab27 effector [66] and also interacts with Munc18/Syntaxin complexes in platelets [61]. SLP proteins contain calcium/lipid-binding, C2 domains and thus could serve as calcium sensors. Despite these data, a clear mechanistic understanding of their function is still lacking.

\section{Sorting Complexes}

Tethering/Sorting complexes appear to be important for granule biogenesis [77]; however, it is unclear how such complexes influence exocytosis. One potential example, the Exocyst, is thought to be important for polarized secretion [78]. Exocyst is a conserved octameric complex that directly interacts with SNAREs and SM proteins [79]. Platelet proteomics studies show that the Exocyst subunits are expressed in stoichiometric amounts [23]. The Exocyst is targeted to mammalian cell membranes via an interaction with a prenylated, raslike GTPase called Ral [80]. Ral is expressed in platelets and is activated to its GTP-bound state following thrombin-treatment [81]. There are two Ral isoforms, A and B; both are present in platelets. Horiuchi and colleagues showed that by blocking Ral-GTP binding to the Sec5/Exoc2 subunit, they could inhibit GppNHp-induced dense granule release from permeabilized platelets [82]. Consistently Ral and Exocyst interact in thrombin-stimulated platelets. Despite these insights, there are many unanswered questions about the roles of Ral and Exocyst. Does the presence of Exocyst imply some polarization of platelet secretion? Ral A and B have distinct functions in other systems [83]. Will that be true in platelets as well? Given the development of Ral inhibitors as anti-cancer drugs [84], it seems important that the roles of this protein and the Exocyst be determined in order to appreciate how these drugs might affect platelet function.

\section{NSF and SNAPs}

The first membrane trafficking proteins purified were the AAA ${ }^{+}$ATPase, $\underline{\text { N-ethylmaleimide }}$

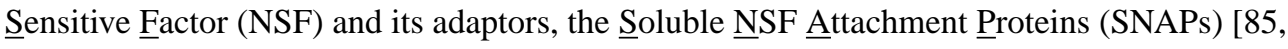
86]. These proteins disassemble spent SNARE complexes, post fusion, and thus are critical for SNARE recycling [87]. Lemons et al. [88] first reported their presence in platelets and Polgar et al. [89] showed that inhibitory peptides that blocked NSF activity also blocked 
release from permeabilized platelets. Consistently, nitrosylation reversibly inhibits platelet NSF, accounting for a portion of the inhibitory effect of NO on platelet exocytosis [90]. Initially, NSF's role was contentious since platelet exocytosis was thought to be a "one shot" event; thus there was no need to recycle spent SNAREs. Subsequent studies suggest that platelets have multiple, membrane fusion/trafficking processes (i.e. endocytosis, autophagy, etc. $[91,92])$ explaining the presence of NSF and SNAPs. However, their role in recycling SNAREs for exocytosis is still puzzling.

\section{Post-Translational Modifications of the Secretory Machinery}

There have been several reports of phosphorylation of platelet secretory machinery components (e.g, Syntaxin 4, Munc18, STXBP5, etc.), although few have definitively linked modifications to exocytosis control $[55,58,93]$. One example where phosphorylation clearly affects function is the phosphorylation of SNAP-23, by I $\kappa$ B kinase (IKK). Originally seen in mast cells, IKK phosphorylates specific serines (Ser95) on SNAP-23, which affects SNARE complex dynamics [42, 94-97]. Consistently, platelet-specific deletion of IKK $\beta$ or treatment with IKK inhibitors blocks platelet secretion from all three granules and leads to a bleeding diathesis [96]. In vitro studies with SNARE-containing proteoliposomes suggest that SNAP-23 phosphorylation enhances membrane fusion rates, though it is not required for fusion. Immunoprecipitation studies show that phosphor-SNAP-23 preferentially incorporates into SNARE complexes in activated platelets.

Another noteworthy post-translational modification is acylation. Proteomics studies had identified a number of acylated proteins in platelets that have thioester-linked fatty acids attached to cysteines [98]. This is particularly important to Syntaxin 11 and SNAP-23, which lack classical transmembrane domains (TMD) but behave as membrane proteins. Both tSNAREs contain cysteine-rich domains (at the C-terminus for Syntaxin 11 and between the two SNARE domains in SNAP-23) that are thought to be acylated. Consistently, treatment of platelet membranes with a thioesterase releases SNAP-23 and affects secretion in permeabilized platelets [99]. The significance of t- SNARE acylation is yet to be understood; however, since neither SNARE has a classical TMD, acylation must affect membrane fusogenicity. Studies using reconstituted proteoliposome fusion assays show that t-SNARE TMDs can be functionally replaced by lipid moieties so long as they are hydrophobic enough. $\mathrm{C}_{15}$ prenyl groups are not sufficiently hydrophobic but $\mathrm{C}_{55}$ groups are [100]. Both SNAP-23 and Syntaxin 11 have multiple potential acylation sites; however, it remains to be determined the extent to which t-SNARE acylation occurs and is controlled in platelets. In other cell types, removal or modification of the t-SNARE cysteine-rich domains does affect secretion [101, 102].

\section{Mechanistic Musings}

Though the relevance of SNAREs is established, the protein-protein interactions leading to membrane fusion are not completely defined in platelets. Clearly, there are more secretory machine elements left to be identified, especially given that we have not filled the gaps between known signaling cascades and secretory machinery. 
As implied by the phenotypes of the platelets lacking specific SNAREs (VAMP-7 ${ }^{-/-}$, VAMP- $8^{-/-}$, Syntaxin $8^{-/-}$and Syntaxin $11 / \mathrm{FHL}^{-/-}$), it seems possible that more than one SNARE complex may mediate granule release. Future studies should focus on determining if different SNARE combinations convey distinct properties to specific membrane fusion events. It seems possible that some complexes will be more fusogenic than others and thus could fine tune release kinetics and perhaps alter platelet releasate composition.

A major question is, "How is secretion controlled by calcium?". Calcium is critical to most regulated secretory processes; yet in platelets, there are no clear calcium sensors that affect secretion. Synaptotagmins, which are calcium sensors in neurons have not been characterized in platelets [68]. Several proteins discussed in this review have calciumbinding domains ( $\mathrm{C} 2$ domains like synaptotagmins) or can be phosphorylated by Protein Kinase C. However, direct mechanistic data are lacking.

A second consideration is whether platelet exocytosis is polarized. While at first glance, it may seem unlikely, there is clear polarity once platelets are adherent. Given the core and shell architecture of a growing thrombus [103], it's plausible that cargo release is oriented: either towards the vascular wall to affect wound healing or towards the vessel lumen to recruit more platelets. The work of Peters et al. [40] clearly shows that VAMP-8- and VAMP-7-positive granules spatially segregate; is that to mediate different release events? Given VAMP-7's role in spreading and the importance of Ral and Exocyst, perhaps the answer is yes.

Finally, are granules the only things secreted from platelets? Cargo that are generally thought to be markers of cellular organelles (i.e., sugar nucleotides from Golgi; PDI from ER; etc.) are detected in platelet releasates and are functionally relevant [104-106]. Do these release events use the same machinery as granules? These are exciting questions that get to the very heart of platelet cell biology and its importance. Their answers are destined to change our views of platelet function and hemostasis.

\section{Acknowledgments}

The authors are immensely grateful to members of the Whiteheart laboratory: Dr. Jinchao Zhang, Meenakshi Banerjee, Alfonso Pepe, Lucy W. Sandmeyer, Thirushan WignaKumar, and Patrick Thompson, for their careful reading of this manuscript and their helpful comments. This work is supported by National Institutes of Health (NIH) HL56652 and by American Heart Association 16GRNT27620001 (to SWW) and American Heart Association predoctoral fellowship 15PRE25550020 (to SJ).

\section{References}

1. Smyth SS, McEver RP, Weyrich AS, Morrell CN, Hoffman MR, Arepally GM, French PA, Dauerman HL, Becker RC, P. Platelet Colloquium. Platelet functions beyond hemostasis. J Thromb Haemost. 2009; 7:1759-1766. [PubMed: 19691483]

2. Tesfamariam B. Involvement of platelets in tumor cell metastasis. Pharmacol Ther. 2016; 157:112119. [PubMed: 26615781]

3. Nurden A, Nurden P. Advances in our understanding of the molecular basis of disorders of platelet function. J Thromb Haemost. 2011; 9(Suppl 1):76-91. [PubMed: 21781244]

4. Fitch-Tewfik JL, Flaumenhaft R. Platelet granule exocytosis: a comparison with chromaffin cells. Front Endocrinol (Lausanne). 2013; 4:77. [PubMed: 23805129] 
5. Golebiewska EM, Poole AW. Platelet secretion: From haemostasis to wound healing and beyond. Blood Rev. 2015; 29:153-162. [PubMed: 25468720]

6. Heijnen H, van der Sluijs P. Platelet secretory behaviour: as diverse as the granules ... or not? J Thromb Haemost. 2015; 13:2141-2151. [PubMed: 26391322]

7. Koseoglu S, Flaumenhaft R. Advances in platelet granule biology. Curr Opin Hematol. 2013; 20:464-471. [PubMed: 23839294]

8. Jonnalagadda D, Izu LT, Whiteheart SW. Platelet secretion is kinetically heterogeneous in an agonist-responsive manner. Blood. 2012; 120:5209-5216. [PubMed: 23086755]

9. Coppinger JA, Cagney G, Toomey S, Kislinger T, Belton O, McRedmond JP, Cahill DJ, Emili A, Fitzgerald DJ, Maguire PB. Characterization of the proteins released from activated platelets leads to localization of novel platelet proteins in human atherosclerotic lesions. Blood. 2004; 103:20962104. [PubMed: 14630798]

10. Maynard DM, Heijnen HF, Horne MK, White JG, Gahl WA. Proteomic analysis of platelet alphagranules using mass spectrometry. J Thromb Haemost. 2007; 5:1945-1955. [PubMed: 17723134]

11. van Holten TC, Bleijerveld OB, Wijten P, de Groot PG, Heck AJ, Barendrecht AD, Merkx TH, Scholten A, Roest M. Quantitative proteomics analysis reveals similar release profiles following specific PAR-1 or PAR-4 stimulation of platelets. Cardiovasc Res. 2014; 103:140-146. [PubMed: 24776597]

12. Wijten P, van Holten T, Woo LL, Bleijerveld OB, Roest M, Heck AJ, Scholten A. High precision platelet releasate definition by quantitative reversed protein profiling-brief report. Arterioscler Thromb Vasc Biol. 2013; 33:1635-1638. [PubMed: 23640497]

13. Chatterjee M, Huang Z, Zhang W, Jiang L, Hultenby K, Zhu L, Hu H, Nilsson GP, Li N. Distinct platelet packaging, release, and surface expression of proangiogenic and antiangiogenic factors on different platelet stimuli. Blood. 2011; 117:3907-3911. [PubMed: 21330475]

14. Italiano JE Jr, Richardson JL, Patel-Hett S, Battinelli E, Zaslavsky A, Short S, Ryeom S, Folkman J, Klement GL. Angiogenesis is regulated by a novel mechanism: pro- and antiangiogenic proteins are organized into separate platelet alpha granules and differentially released. Blood. 2008; 111:1227-1233. [PubMed: 17962514]

15. Ma L, Perini R, McKnight W, Dicay M, Klein A, Hollenberg MD, Wallace JL. Proteinase-activated receptors 1 and 4 counter-regulate endostatin and VEGF release from human platelets. Proc Natl Acad Sci U S A. 2005; 102:216-220. [PubMed: 15615851]

16. Kamykowski J, Carlton P, Sehgal S, Storrie B. Quantitative immunofluorescence mapping reveals little functional coclustering of proteins within platelet alpha-granules. Blood. 2011; 118:1370 1373. [PubMed: 21622648]

17. Sehgal S, Storrie B. Evidence that differential packaging of the major platelet granule proteins von Willebrand factor and fibrinogen can support their differential release. J Thromb Haemost. 2007; 5:2009-2016. [PubMed: 17650077]

18. White JG, Krumwiede MD. The down-side of platelet interaction with surfaces. Eur J Cell Biol. 1994; 65:178-188. [PubMed: 7889989]

19. Morgenstern E. The formation of compound granules from different types of secretory organelles in human platelets (dense granules and alpha-granules). A cryofixation/- substitution study using serial sections. Eur J Cell Biol. 1995; 68:183-190. [PubMed: 8575464]

20. Kloepper TH, Kienle CN, Fasshauer D. An elaborate classification of SNARE proteins sheds light on the conservation of the eukaryotic endomembrane system. Mol Biol Cell. 2007; 18:3463-3471. [PubMed: 17596510]

21. Fasshauer D, Sutton RB, Brunger AT, Jahn R. Conserved structural features of the synaptic fusion complex: SNARE proteins reclassified as Q- and R-SNAREs. Proc Natl Acad Sci U S A. 1998; 95:15781-15786. [PubMed: 9861047]

22. Jahn R, Scheller RH. SNAREs-engines for membrane fusion. Nat Rev Mol Cell Biol. 2006; 7:631-643. [PubMed: 16912714]

23. Burkhart JM, Schumbrutzki C, Wortelkamp S, Sickmann A, Zahedi RP. Systematic and quantitative comparison of digest efficiency and specificity reveals the impact of trypsin quality on MS-based proteomics. J Proteomics. 2012; 75:1454-1462. [PubMed: 22166745] 
24. Graham GJ, Ren Q, Dilks JR, Blair P, Whiteheart SW, Flaumenhaft R. Endobrevin/VAMP-8dependent dense granule release mediates thrombus formation in vivo. Blood. 2009; 114:10831090. [PubMed: 19395672]

25. Feng D, Crane K, Rozenvayn N, Dvorak AM, Flaumenhaft R. Subcellular distribution of 3 functional platelet SNARE proteins: human cellubrevin, SNAP-23, and syntaxin 2. Blood. 2002; 99:4006-4014. [PubMed: 12010801]

26. Flaumenhaft R, Croce K, Chen E, Furie B, Furie BC. Proteins of the exocytotic core complex mediate platelet alpha-granule secretion. Roles of vesicle-associated membrane protein, SNAP-23, and syntaxin 4. J Biol Chem. 1999; 274:2492-2501. [PubMed: 9891020]

27. Polgar J, Chung SH, Reed GL. Vesicle-associated membrane protein 3 (VAMP-3) and VAMP-8 are present in human platelets and are required for granule secretion. Blood. 2002; 100:1081-1083. [PubMed: 12130530]

28. Schraw TD, Rutledge TW, Crawford GL, Bernstein AM, Kalen AL, Pessin JE, Whiteheart SW. Granule stores from cellubrevin/VAMP-3 null mouse platelets exhibit normal stimulus-induced release. Blood. 2003; 102:1716-1722. [PubMed: 12738662]

29. Koseoglu S, Peters CG, Fitch-Tewfik JL, Aisiku O, Danglot L, Galli T, Flaumenhaft R. VAMP-7 links granule exocytosis to actin reorganization during platelet activation. Blood. 2015; 126:651660. [PubMed: 25999457]

30. Ren Q, Barber HK, Crawford GL, Karim ZA, Zhao C, Choi W, Wang CC, Hong W, Whiteheart SW. Endobrevin/VAMP-8 is the primary v-SNARE for the platelet release reaction. Mol Biol Cell. 2007; 18:24-33. [PubMed: 17065550]

31. Schiavo G, Matteoli M, Montecucco C. Neurotoxins affecting neuroexocytosis. Physiol Rev. 2000; 80:717-766. [PubMed: 10747206]

32. Galli T, Zahraoui A, Vaidyanathan VV, Raposo G, Tian JM, Karin M, Niemann H, Louvard D. A novel tetanus neurotoxin-insensitive vesicle-associated membrane protein in SNARE complexes of the apical plasma membrane of epithelial cells. Mol Biol Cell. 1998; 9:1437-1448. [PubMed: 9614185]

33. Borisovska M, Zhao Y, Tsytsyura Y, Glyvuk N, Takamori S, Matti U, Rettig J, Sudhof T, Bruns D. v-SNAREs control exocytosis of vesicles from priming to fusion. EMBO J. 2005; 24:2114-2126. [PubMed: 15920476]

34. Sander LE, Frank SP, Bolat S, Blank U, Galli T, Bigalke H, Bischoff SC, Lorentz A. Vesicle associated membrane protein (VAMP)-7 and VAMP-8, but not VAMP-2 or VAMP-3, are required for activation-induced degranulation of mature human mast cells. Eur J Immunol. 2008; 38:855863. [PubMed: 18253931]

35. Tiwari N, Wang CC, Brochetta C, Scandiuzzi L, Hong W, Blank U. Increased formation of VAMP-3-containing SNARE complexes in mast cells from VAMP-8 deficient cells. appetite. Inflamm Res. 2009; 58(Suppl 1):13-14. [PubMed: 19274433]

36. Shiffman D, O’Meara ES, Bare LA, Rowland CM, Louie JZ, Arellano AR, Lumley T, Rice K, Iakoubova O, Luke MM, Young BA, Malloy MJ, Kane JP, Ellis SG, Tracy RP, Devlin JJ, Psaty BM. Association of gene variants with incident myocardial infarction in the Cardiovascular Health Study. Arterioscler Thromb Vasc Biol. 2008; 28:173-179. [PubMed: 17975119]

37. Shiffman D, Rowland CM, Louie JZ, Luke MM, Bare LA, Bolonick JI, Young BA, Catanese JJ, Stiggins CF, Pullinger CR, Topol EJ, Malloy MJ, Kane JP, Ellis SG, Devlin JJ. Gene variants of VAMP8 and HNRPUL1 are associated with early- onset myocardial infarction. Arterioscler Thromb Vasc Biol. 2006; 26:1613-1618. [PubMed: 16690874]

38. Kondkar AA, Bray MS, Leal SM, Nagalla S, Liu DJ, Jin Y, Dong JF, Ren Q, Whiteheart SW, Shaw $\mathrm{C}$, Bray PF. VAMP8/endobrevin is overexpressed in hyperreactive human platelets: suggested role for platelet microRNA. J Thromb Haemost. 2010; 8:369-378. [PubMed: 19943878]

39. Schafer IB, Hesketh GG, Bright NA, Gray SR, Pryor PR, Evans PR, Luzio JP, Owen DJ. The binding of Varp to VAMP7 traps VAMP7 in a closed, fusogenically inactive conformation. Nat Struct Mol Biol. 2012; 19:1300-1309. [PubMed: 23104059]

40. Peters CG, Michelson AD, Flaumenhaft R. Granule exocytosis is required for platelet spreading: differential sorting of alpha-granules expressing VAMP-7. Blood. 2012; 120:199-206. [PubMed: 22589474] 
41. Mollinedo F, Calafat J, Janssen H, Martin-Martin B, Canchado J, Nabokina SM, Gajate C. Combinatorial SNARE complexes modulate the secretion of cytoplasmic granules in human neutrophils. J Immunol. 2006; 177:2831-2841. [PubMed: 16920918]

42. Puri N, Roche PA. Mast cells possess distinct secretory granule subsets whose exocytosis is regulated by different SNARE isoforms. Proc Natl Acad Sci U S A. 2008; 105:2580-2585. [PubMed: 18250339]

43. Ren QS, Ye SJ, Whiteheart SW. The platelet release reaction: just when you thought platelet secretion was simple. Current Opinion in Hematology. 2008; 15:537-541. [PubMed: 18695380]

44. Chen D, Bernstein AM, Lemons PP, Whiteheart SW. Molecular mechanisms of platelet exocytosis: role of SNAP-23 and syntaxin 2 in dense core granule release. Blood. 2000; 95:921-929. [PubMed: 10648404]

45. Chen D, Lemons PP, Schraw T, Whiteheart SW. Molecular mechanisms of platelet exocytosis: role of SNAP-23 and syntaxin 2 and 4 in lysosome release. Blood. 2000; 96:1782-1788. [PubMed: 10961877]

46. Lemons PP, Chen D, Whiteheart SW. Molecular mechanisms of platelet exocytosis: requirements for alpha-granule release. Biochem Biophys Res Commun. 2000; 267:875-880. [PubMed: 10673384]

47. Williams CM, Savage JS, Harper MT, Moore SF, Hers I, Poole AW. Identification of roles for the SNARE-associated protein, SNAP29, in mouse platelets. Platelets. 2016; 27:286-294. [PubMed: 26587753]

48. Ye S, Karim ZA, Al Hawas R, Pessin JE, Filipovich AH, Whiteheart SW. Syntaxin-11, but not syntaxin-2 or syntaxin-4, is required for platelet secretion. Blood. 2012; 120:2484-2492. [PubMed: 22767500]

49. Golebiewska EM, Harper MT, Williams CM, Savage JS, Goggs R, Fischer von Mollard G, Poole AW. Syntaxin 8 regulates platelet dense granule secretion, aggregation, and thrombus stability. $\mathbf{J}$ Biol Chem. 2015; 290:1536-1545. [PubMed: 25404741]

50. Archbold JK, Whitten AE, Hu SH, Collins BM, Martin JL. SNARE-ing the structures of Sec1/ Munc18 proteins. Curr Opin Struct Biol. 2014; 29:44-51. [PubMed: 25282382]

51. Rehman A, Archbold JK, Hu SH, Norwood SJ, Collins BM, Martin JL. Reconciling the regulatory role of Munc18 proteins in SNARE-complex assembly. IUCrJ. 2014; 1:505-513.

52. Bem D, Smith H, Banushi B, Burden JJ, White IJ, Hanley J, Jeremiah N, Rieux-Laucat F, Bettels R, Ariceta G, Mumford AD, Thomas SG, Watson SP, Gissen P. VPS33B regulates protein sorting into and maturation of alpha-granule progenitor organelles in mouse megakaryocytes. Blood. 2015; 126:133-143. [PubMed: 25947942]

53. Huizing M, Didier A, Walenta J, Anikster Y, Gahl WA, Kramer H. Molecular cloning and characterization of human VPS18, VPS 11, VPS16, and VPS33. Gene. 2001; 264:241-247. [PubMed: 11250079]

54. Al Hawas R, Ren Q, Ye S, Karim ZA, Filipovich AH, Whiteheart SW. Munc18b/STXBP2 is required for platelet secretion. Blood. 2012; 120:2493-2500. [PubMed: 22791290]

55. Houng A, Polgar J, Reed GL. Munc18-syntaxin complexes and exocytosis in human platelets. J Biol Chem. 2003; 278:19627-19633. [PubMed: 12649283]

56. Schraw TD, Crawford GL, Ren Q, Choi W, Thurmond DC, Pessin J, Whiteheart SW. Platelets from Munc18c heterozygous mice exhibit normal stimulus-induced release. Thromb Haemost. 2004; 92:829-837. [PubMed: 15467915]

57. Reed GL, Houng AK, Fitzgerald ML. Human platelets contain SNARE proteins and a Sec1p homologue that interacts with syntaxin 4 and is phosphorylated after thrombin activation: Implications for platelet secretion. Blood. 1999; 93:2617-2626. [PubMed: 10194441]

58. Schraw TD, Lemons PP, Dean WL, Whiteheart SW. A role for Sec1/Munc18 proteins in platelet exocytosis. Biochem J. 2003; 374:207-217. [PubMed: 12773094]

59. Fujita Y, Shirataki H, Sakisaka T, Asakura T, Ohya T, Kotani H, Yokoyama S, Nishioka H, Matsuura Y, Mizoguchi A, Scheller RH, Takai Y. Tomosyn: a syntaxin-1-binding protein that forms a novel complex in the neurotransmitter release process. Neuron. 1998; 20:905-915. [PubMed: 9620695] 
60. Ashery U, Bielopolski N, Barak B, Yizhar O. Friends and foes in synaptic transmission: the role of tomosyn in vesicle priming. Trends Neurosci. 2009; 32:275-282. [PubMed: 19307030]

61. Ye S, Huang Y, Joshi S, Zhang J, Yang F, Zhang G, Smyth SS, Li Z, Takai Y, Whiteheart SW. Platelet secretion and hemostasis require syntaxin-binding protein STXBP5. J Clin Invest. 2014; 124:4517-4528. [PubMed: 25244094]

62. Smith NL, Rice KM, Bovill EG, Cushman M, Bis JC, McKnight B, Lumley T, Glazer NL, van Hylckama Vlieg A, Tang W, Dehghan A, Strachan DP, O'Donnell CJ, Rotter JI, Heckbert SR, Psaty BM, Rosendaal FR. Genetic variation associated with plasma von Willebrand factor levels and the risk of incident venous thrombosis. Blood. 2011; 117:6007-6011. [PubMed: 21163921]

63. van Loon JE, Leebeek FW, Deckers JW, Dippel DW, Poldermans D, Strachan DP, Tang W, O'Donnell CJ, Smith NL, de Maat MP. Effect of genetic variations in syntaxin-binding protein-5 and syntaxin- 2 on von Willebrand factor concentration and cardiovascular risk. Circ Cardiovasc Genet. 2010; 3:507-512. [PubMed: 21156930]

64. Zhu Q, Yamakuchi M, Ture S, de la Luz Garcia-Hernandez M, Ko KA, Modjeski KL, LoMonaco MB, Johnson AD, O’Donnell CJ, Takai Y, Morrell CN, Lowenstein CJ. Syntaxin-binding protein STXBP5 inhibits endothelial exocytosis and promotes platelet secretion. J Clin Invest. 2014; 124:4503-4516. [PubMed: 25244095]

65. van Loon JE, Sanders YV, de Wee EM, Kruip MJ, de Maat MP, Leebeek FW. Effect of genetic variation in STXBP5 and STX2 on von Willebrand factor and bleeding phenotype in type 1 von Willebrand disease patients. PLoS One. 2012; 7:e40624. [PubMed: 22792389]

66. Fukuda M. Rab27 effectors, pleiotropic regulators in secretory pathways. Traffic. 2013; 14:949963. [PubMed: 23678941]

67. Tolmachova T, Abrink M, Futter CE, Authi KS, Seabra MC. Rab27b regulates number and secretion of platelet dense granules. Proc Natl Acad Sci U S A. 2007; 104:5872-5877. [PubMed: 17384153]

68. Rizo J, Xu J. The Synaptic Vesicle Release Machinery. Annu Rev Biophys. 2015; 44:339-367. [PubMed: 26098518]

69. Fukuda M. Rab27 and its effectors in secretory granule exocytosis: a novel docking machinery composed of a Rab27.effector complex. Biochem Soc Trans. 2006; 34:691-695. [PubMed: 17052176]

70. Chicka MC, Ren Q, Richards D, Hellman LM, Zhang J, Fried MG, Whiteheart SW. Role of Munc13-4 as a Ca2+-dependent tether during platelet secretion. Biochem J. 2016; 473:627-639. [PubMed: 26637270]

71. Ren Q, Wimmer C, Chicka MC, Ye S, Ren Y, Hughson FM, Whiteheart SW. Munc13-4 is a limiting factor in the pathway required for platelet granule release and hemostasis. Blood. 2010; 116:869-877. [PubMed: 20435885]

72. Harper MT, van den Bosch MT, Hers I, Poole AW. Platelet dense granule secretion defects may obscure alpha-granule secretion mechanisms: evidence from Munc13-4-deficient platelets. Blood. 2015; 125:3034-3036. [PubMed: 25953980]

73. Sharda A, Kim SH, Jasuja R, Gopal S, Flaumenhaft R, Furie BC, Furie B. Defective PDI release from platelets and endothelial cells impairs thrombus formation in Hermansky-Pudlak syndrome. Blood. 2015; 125:1633-1642. [PubMed: 25593336]

74. Meng R, Wu J, Harper DC, Wang Y, Kowalska MA, Abrams CS, Brass LF, Poncz M, Stalker TJ, Marks MS. Defective release of alpha granule and lysosome contents from platelets in mouse Hermansky-Pudlak syndrome models. Blood. 2015; 125:1623-1632. [PubMed: 25477496]

75. Neumuller O, Hoffmeister M, Babica J, Prelle C, Gegenbauer K, Smolenski AP. Synaptotagminlike protein 1 interacts with the GTPase-activating protein Rap1GAP2 and regulates dense granule secretion in platelets. Blood. 2009; 114:1396-1404. [PubMed: 19528539]

76. Hampson A, O'Connor A, Smolenski A. Synaptotagmin-like protein 4 and Rab8 interact and increase dense granule release in platelets. J Thromb Haemost. 2013; 11:161-168.

77. Masliah-Planchon J, Darnige L, Bellucci S. Molecular determinants of platelet delta storage pool deficiencies: an update. Br J Haematol. 2013; 160:5-11. [PubMed: 23025459]

78. Liu J, Guo W. The exocyst complex in exocytosis and cell migration. Protoplasma. 2012; 249:587597. [PubMed: 21997494] 
79. Wu B, Guo W. The Exocyst at a Glance. J Cell Sci. 2015; 128:2957-2964. [PubMed: 26240175]

80. Gentry LR, Martin TD, Reiner DJ, Der CJ. Ral small GTPase signaling and oncogenesis: More than just 15minutes of fame. Biochim Biophys Acta. 2014; 1843:2976-2988. [PubMed: 25219551]

81. Wolthuis RM, Franke B, van Triest M, Bauer B, Cool RH, Camonis JH, Akkerman JW, Bos JL. Activation of the small GTPase Ral in platelets. Mol Cell Biol. 1998; 18:2486-2491. [PubMed: 9566869]

82. Kawato M, Shirakawa R, Kondo H, Higashi T, Ikeda T, Okawa K, Fukai S, Nureki O, Kita T, Horiuchi H. Regulation of platelet dense granule secretion by the Ral GTPase-exocyst pathway. J Biol Chem. 2008; 283:166-174. [PubMed: 17938170]

83. Shirakawa R, Horiuchi H. Ral GTPases: crucial mediators of exocytosis and tumourigenesis. J Biochem. 2015; 157:285-299. [PubMed: 25796063]

84. Yan C, Liu D, Li L, Wempe MF, Guin S, Khanna M, Meier J, Hoffman B, Owens C, Wysoczynski CL, Nitz MD, Knabe WE, Ahmed M, Brautigan DL, Paschal BM, Schwartz MA, Jones DN, Ross $\mathrm{D}$, Meroueh SO, Theodorescu D. Discovery and characterization of small molecules that target the GTPase Ral. Nature. 2014; 515:443-447. [PubMed: 25219851]

85. Block MR, Glick BS, Wilcox CA, Wieland FT, Rothman JE. Purification of an N-ethylmaleimidesensitive protein catalyzing vesicular transport. Proc Natl Acad Sci U S A. 1988; 85:7852-7856. [PubMed: 3186695]

86. Clary DO I, Griff C, Rothman JE. SNAPs, a family of NSF attachment proteins involved in intracellular membrane fusion in animals and yeast. Cell. 1990; 61:709-721. [PubMed: 2111733]

87. Zhao C, Smith EC, Whiteheart SW. Requirements for the catalytic cycle of the N-ethylmaleimideSensitive Factor (NSF). Biochim Biophys Acta. 2012; 1823:159-171. [PubMed: 21689688]

88. Lemons PP, Chen D, Bernstein AM, Bennett MK, Whiteheart SW. Regulated secretion in platelets: identification of elements of the platelet exocytosis machinery. Blood. 1997; 90:1490-1500. [PubMed: 9269766]

89. Polgar J, Reed GL. A critical role for N-ethylmaleimide-sensitive fusion protein (NSF) in platelet granule secretion. Blood. 1999; 94:1313-1318. [PubMed: 10438719]

90. Morrell CN, Matsushita K, Chiles K, Scharpf RB, Yamakuchi M, Mason RJ, Bergmeier W, Mankowski JL, Baldwin WM 3rd, Faraday N, Lowenstein CJ. Regulation of platelet granule exocytosis by S-nitrosylation. Proc Natl Acad Sci U S A. 2005; 102:3782-3787. [PubMed: 15738422]

91. Huang Y, Joshi S, Xiang B, Kanaho Y, Li Z, Bouchard BA, Moncman CL, Whiteheart SW. Arf6 controls platelet spreading and clot retraction via integrin alphaIIbbeta3 trafficking. Blood. 2016; 127:1459-1467. [PubMed: 26738539]

92. Ouseph MM, Huang Y, Banerjee M, Joshi S, MacDonald L, Zhong Y, Liu H, Li X, Xiang B, Zhang G, Komatsu M, Yue Z, Li Z, Storrie B, Whiteheart SW, Wang QJ. Autophagy is induced upon platelet activation and is essential for hemostasis and thrombosis. Blood. 2015; 126:1224-1233. [PubMed: 26209658]

93. Polgar J, Lane WS, Chung SH, Houng AK, Reed GL. Phosphorylation of SNAP-23 in activated human platelets. J Biol Chem. 2003; 278:44369-44376. [PubMed: 12930825]

94. Cabaniols JP, Ravichandran V, Roche PA. Phosphorylation of SNAP-23 by the novel kinase SNAK regulates t-SNARE complex assembly. Mol Biol Cell. 1999; 10:4033-4041. [PubMed: 10588641]

95. Hepp R, Puri N, Hohenstein AC, Crawford GL, Whiteheart SW, Roche PA. Phosphorylation of SNAP-23 regulates exocytosis from mast cells. J Biol Chem. 2005; 280:6610-6620. [PubMed: 15611044]

96. Karim ZA, Zhang J, Banerjee M, Chicka MC, Al Hawas R, Hamilton TR, Roche PA, Whiteheart SW. IkappaB kinase phosphorylation of SNAP-23 controls platelet secretion. Blood. 2013; 121:4567-4574. [PubMed: 23613522]

97. Suzuki K, Verma IM. Phosphorylation of SNAP-23 by IkappaB kinase 2 regulates mast cell degranulation. Cell. 2008; 134:485-495. [PubMed: 18692471]

98. Dowal L, Yang W, Freeman MR, Steen H, Flaumenhaft R. Proteomic analysis of palmitoylated platelet proteins. Blood. 2011; 118:e62-73. [PubMed: 21813449] 
99. Sim DS, Dilks JR, Flaumenhaft R. Platelets possess and require an active protein palmitoylation pathway for agonist-mediated activation and in vivo thrombus formation. Arterioscler Thromb Vasc Biol. 2007; 27:1478-1485. [PubMed: 17303775]

100. McNew JA, Weber T, Parlati F, Johnston RJ, Melia TJ, Sollner TH, Rothman JE. Close is not enough: SNARE-dependent membrane fusion requires an active mechanism that transduces force to membrane anchors. J Cell Biol. 2000; 150:105-117. [PubMed: 10893260]

101. Salaun C, Gould GW, Chamberlain LH. The SNARE proteins SNAP-25 and SNAP-23 display different affinities for lipid rafts in PC12 cells. Regulation by distinct cysteine-rich domains. J Biol Chem. 2005; 280:1236-1240. [PubMed: 15542596]

102. Valdez AC, Cabaniols JP, Brown MJ, Roche PA. Syntaxin 11 is associated with SNAP-23 on late endosomes and the trans-Golgi network. J Cell Sci. 1999; 112(Pt 6):845-854. [PubMed: 10036234]

103. Welsh JD, Stalker TJ, Voronov R, Muthard RW, Tomaiuolo M, Diamond SL, Brass LF. A systems approach to hemostasis: 1 . The interdependence of thrombus architecture and agonist movements in the gaps between platelets. Blood. 2014; 124:1808-1815. [PubMed: 24951424]

104. Crescente M, Pluthero FG, Li L, Lo RW, Walsh TG, Schenk MP, Holbrook LM, Louriero S, Ali MS, Vaiyapuri S, Falet H, Jones IM, Poole AW, Kahr WH, Gibbins JM. Intracellular Trafficking, Localization, and Mobilization of Platelet-Borne Thiol Isomerases. Arterioscler Thromb Vasc Biol. 2016; 36:1164-1173. [PubMed: 27079884]

105. Lee MM, Nasirikenari M, Manhardt CT, Ashline DJ, Hanneman AJ, Reinhold VN, Lau JT. Platelets support extracellular sialylation by supplying the sugar donor substrate. J Biol Chem. 2014; 289:8742-8748. [PubMed: 24550397]

106. Wandall HH, Rumjantseva V, Sorensen AL, Patel-Hett S, Josefsson EC, Bennett EP, Italiano JE Jr, Clausen H, Hartwig JH, Hoffmeister KM. The origin and function of platelet glycosyltransferases. Blood. 2012; 120:626-635. [PubMed: 22613794] 


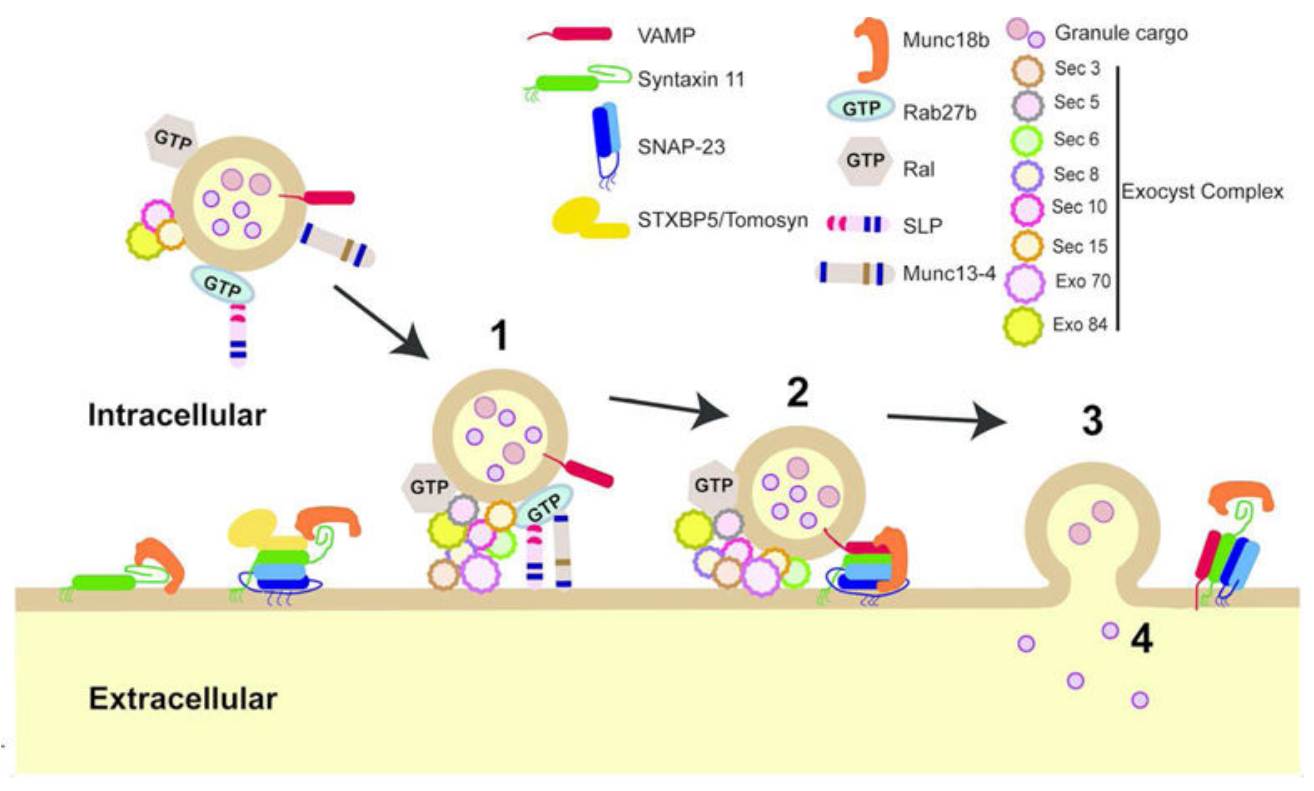

Figure 1. Pathway of SNARE-Mediated Platelet Granule Release

Platelet exocytosis is a pathway of protein-protein interactions leading from 1) granule docking, 2) SNARE engagement to 3) membrane fusion and 4) cargo release. The interactions and their proposed order of occurrence are depicted in the schematic. The machinery which could be on the granules includes: v-SNAREs (Vesicle Associated Membrane Protein/VAMPs); Munc13-4 and synaptotagmin like protein (SLP); small GTPases Rab and Ral; and the Exocyst complex. The machinery on the plasma membrane includes: t-SNARE heterodimer of Syntaxin 11 and SNAP 23; the Syntaxin-chaperone Munc18b; and the t-SNARE regulator STXBP5/Tomosyn-1. Also depicted are domains in each protein which contribute to protein function and thus platelet exocytosis: blue lines, C2 domains in Munc13-4 and SLP; brown line, Munc homology domain in Munc13-4; red lines, SLP homology domain in SLP; rounded rectangles, SNARE domain. 


\section{Table 1}

Secretory Machinery in Platelets

\begin{tabular}{|c|c|c|c|}
\hline Protein & Gene & Aliases (in Homo sapiens) & Functional References \\
\hline \multicolumn{4}{|c|}{ v-SNAREs (R - SNAREs) } \\
\hline VAMP-2 & VAMP2 & SYB2, VAMP-2 & {$[30]$} \\
\hline VAMP-3 & VAMP3 & CEB & {$[25-28]$} \\
\hline VAMP-4 & VAMP4 & VAMP-4, VAMP24 & \\
\hline VAMP-5 & VAMP5 & & \\
\hline VAMP-7 & VAMP7 & SYBL1, TIVAMP, VAMP-7, TI-VAMP & {$[29]$} \\
\hline VAMP-8 & VAMP8 & EDB, VAMP-8 & {$[24,30]$} \\
\hline \multicolumn{4}{|c|}{ t - SNARES (Q-SNAREs) } \\
\hline Syntaxin 2 & STX2 & EPM, EPIM, STX2A, STX2B, STX2C & {$[44,45]$} \\
\hline Syntaxin 4 & STX4 & STX4A, p35-2 & {$[26,44-46,88]$} \\
\hline Syntaxin 8 & STX8 & CARB & [49] \\
\hline Syntaxin 11 & STX11 & FHL4, HLH4, HPLH4 & [48] \\
\hline SNAP-23 & SNAP23 & SNAP-23, SNAP23A, SNAP23B, HsT17016 & {$[26,44-46,88]$} \\
\hline SNAP-25 & SNAP25 & $\begin{array}{l}\text { SUP, RIC4, SEC9, SNAP, CMS18, RIC-4, SNAP-2,, bA416N4.2, } \\
\text { dJ1068F16.2 }\end{array}$ & \\
\hline SNAP-29 & SNAP29 & CEDNIK, SNAP-29 & [47] \\
\hline \multicolumn{4}{|l|}{ SNARE Regulators } \\
\hline Munc18a & STXBP1 & P67 NSEC1, UNC18, RBSEC1, MUNC18-1 & {$[58]$} \\
\hline Munc18 b & STXBP2 & FHL5, UNC18B, Hunc18b, UNC18-2, pp10122, MUNC18-2 & {$[54]$} \\
\hline Munc18c & STXBP3 & PSP, MUNC18C, UNC-18C, MUNC18-3 & [57] \\
\hline a-Synuclein & SNCA & PD1, NACP, PARK1, PARK4 & unpublished \\
\hline STXBP5/Tomosyn 1 & STXBP5 & LGL3, LLGL3, Nbla04300 & {$[61,64]$} \\
\hline SLP4/Granuphilin & SYTL4 & SLP4 & [76] \\
\hline a-SNAP & NAPA & SNAPA & unpublished \\
\hline NSF & NSF & SKD2 & [89] and unpublished \\
\hline$\gamma$-SNAP & NAPG & GAMMASNAP & \\
\hline IKK-a & CHUK & IKK1, IKKA, IKBKA, TCF16, NFKBIKA, IKK-alpha & \\
\hline IKK- $\beta$ & IKBKB & IKK2, IKKB, IMD15, NFKBIKB, IKK-beta & [96] \\
\hline IKK- $\gamma$ & IKBKG & $\begin{array}{l}\text { IP, IP1, IP2, FIP3, IKKG, IPD2, NEMO, FIP-3, Fip3p, IMD33, AMCBX1, } \\
\text { IKKAP1, ZC2HC9, IKK-gamma }\end{array}$ & \\
\hline \multicolumn{4}{|l|}{ Tethering Factors } \\
\hline Munc13-4 & UNC13D & FHL3, HLH3, HPLH3, Munc13-4 & [71] \\
\hline Rab 27b & RAB27B & $\mathrm{C} 25 \mathrm{KG}$ & {$[67]$} \\
\hline SLP1 & SYTL1 & JFC1, SLP1 & {$[75]$} \\
\hline \multicolumn{4}{|l|}{ Exocyst Components } \\
\hline $\operatorname{Sec} 3$ & EXOC1 & SEC3, SEC3P, BM-102, SEC3L1 & \\
\hline $\operatorname{Sec} 5$ & EXOC2 & SEC5, Sec5p, SEC5L1 & {$[82]$} \\
\hline
\end{tabular}




\begin{tabular}{|l|l|l|l|}
\hline Protein & Gene & Aliases (in Homo sapiens) & Functional References \\
\hline Sec6 & EXOC3 & SEC6, Sec6p, SEC6L1 & \\
\hline Sec8 & EXOC4 & SEC8, Sec8p, SEC8L1 & \\
\hline Sec10 & EXOC5 & SEC10, HSEC10, SEC10P, PRO1912, SEC10L1 & \\
\hline Sec15 & EXOC6 & SEC15, EXOC6A, SEC15L, Sec15p, SEC15L1, SEC15L3 & \\
\hline Exo70 & EXOC7 & EX070, EXO70, EXOC1, 2-5-3p, Exo70p, YJL085W & \\
\hline Exo84 & EXOC8 & EXO84, SEC84, Exo84p & [82] \\
\hline Ral A & RALA & RAL & \\
\hline Ral B & RALB & & \\
\hline
\end{tabular}

